\title{
Penguatan Nilai-Nilai Karakter Santri-Santriwati Melalui Bacaan Al-Qur'an Di TPQ Al-Khairat Lingkungan Rasabou Kelurahan Jatibaru Kecamatan Asakota Kota Bima
}

\author{
Abd. Salam \\ Dosen STIT Sunan Giri Bima \\ Email: salamrahmania1234@yahoo.co.id
}

\begin{abstract}
The strengthening of the noble character is greatly influenced by the character values ie; Religious Value, Integrity Value, Nationalist Value, Independent Value, Gotong Royong Value, Patient Value study. If the six values have been reinforced by santri-santriwati, it will arise and will grow its character in implementing the teachings of his religion. Therefore, the values of character reinforcement must be instilled in the students, including the teachings to read Al-Qur'an seriously by using techniques and methods in accordance with the development of children, in order to know, live and practice read Alqur'an in daily life. And can strengthen its character through reading Alqur'an.Penelitian aims to examine 1.) How Strengthening the Values of Santri-Santriwati Character Through the Reading of the Qur'an in TPQ Al-Khairat Ling. Rasabou Kel. Jatibaru Kec. Asakota Kota Bima.2.) What Is Meaning and Purpose Read Al-Qur'anni TPQ Al-Khairat. So also Reading Al-qur'an with the beautiful, art and songs will form morals, Islamic Values, because by reading Al-qur'an with khusyu akan embedded morals, in it is the values of Islam, al-Qur'anpun as a cure for liver disease, cleansing of the liver, guidance, light, science, and will give serenity to the heart. So descended alqur'an and bacaanya serve as worship.
\end{abstract}

Keywords: Strengthening of Character Values, Reading the Qur'an.

\section{PENDAHULUAN}

Pendidikan karakter akhir-akhir ini semakin banyak diperbincangkan di tengahtengah masyarakat Indonesia, terutama oleh kalangan akademisi.Sikap dan perilaku masyarakat dan bangsa Indonesia sekarang cenderung mengabaikan nilai-nilai luhur yang sudah lama dijunjung tinggi dan mengakar dalam sikap dan perilaku sehari-hari. Nilainilai karakter mulia, seperti kejujuran, kesantunan, kebersamaan, dan religius, sedikit demi sedikit mulai tergerus oleh budaya asing yang cenderung hedonistik, materialistik, dan individualistik, sehingga nilai-nilai karakter tersebut tidak lagi dianggap penting jika bertentangan dengan tujuan yang ingin diperoleh.

Salahudin, Anas dan Alkrienciehie, Irwanto (2013:49) mengatakan bahwa, hakikat pendidikan adalah mengembalikan nilai-nilai ilahiah pada manusia (fitrah) 
dengan bimbingan Al-Qur'an dan As-Sunnah (hadits) sehingga menjadi manusia yang berakhlak mulia (insan kamil).

Berdasarkan tujuan dari penguatan karakter pada baca Al-qur'an tersebut, yaitu berupaya membentuk watak manusia yang memiliki sikap mental dan prilaku yang baik (akhlaqul karimah), manusia yang bermoral dan memiliki etika serta sopan santun, baik terhadap diri pribadi Santri-Santriwati, orang lain, lingkungan dan Tuhan. Maka penulis berusaha mengkaji PenguatanNilai-nilai Karakter Santri-Santriwati Melalui Bacaan AlQur'an di TPQ Al-Khairat Ling. Rasabou Kel. Jatibaru Kec. Asakota Kota Bima.

\section{Memperkuat Kembali Nilai-nilai Karakter pada Santri-Santriwati}

Setiap orang yang akan melaksanakan tugasnya sebagai guru ngaji harus memiliki karakter, yang sesuai dengan ajaran Islam, sebagai guru ngaji dituntut memberi keteladan kepada Santri-Santriwati. Daradjat (1993:98), mengemukakan bahwa Guru merupakan tokoh yang akan ditiru dan diteladani, dalam melaksanakan tugasnya sebagai pendidik, dia harus tabah dan tahu cara memecahkan berbagai kesulitan dalam tugasnya sebagai pendidik. Sebagai manusia biasa, guru ngaji tidak terlepas dari berbagai kesulitan hidup, kebutuhan hidup rumah tangga, pergaulan sosial dan keadaan ekonomi, kesejahteraan supaya tidak terganggu kelancaran tugas dalam proses belajar mengajar bacaan Al-Qur'an. Keadaan guru ngaji tersebut dapat memperkuat serta menumbuhkan karakter yang baik.

Dalam proses penguatan karakter pada Santri-Santriwati, berlangsung secara berangsur-angsur, bukanlah hal yang sekaligus terjadi melainkan sesuatu yang berkembang secara bertahap, upaya pembentukan karakter terhadap Santri-Santriwati merupakan suatu kegiatan proses akhir dari perkembangan fisik/psikis manusia yang berlangsung dengan baik, tentu akan menghasilkan suatu karakter yang harmonis.(Darajat, 1993:98).

Hidup manusia senantiasa mengandung unsur dinamisme yaitu perubahanperubahan secara progresif untuk menuju suatu integrasi pada akhirnya melahirkan karakteristik. Marimba (1989) mengemukakan ada tiga yaitu: 1. Aspek kejasmaniaan; meliputi tingkah laku luas yang mudah nampak dan ketahuan dari luar misalnya cara-cara berbuat, cara-cara berbicara; 2. Aspek kejiwaan; meliputi aspek-aspek yang tidak segera dapat dilihat dan ketahuan dari luar misalnya cara berfikir, sikap dan minat; 3. Aspek keharmonisan yang luhur; meliputi aspek-aspek kejiwaan yang lebih abstrak yaitu filsafat 
hidup dan kepercayaan ini meliputi sistem nilai-nilai yang telah meresap didalam karakter itu, telah menjadi bagian dan mendarah daging dalam karakter itu yang mengarahkan dan memberi corak seluruh kehidupanm individu itu bagi orang-orang yang beragama. Aspek-aspek inilah yang menuntutnya kearah kebahagiaan, bukan saja didunia tapi juga diakhirat, aspek-aspek inilah memberi kualitas karakter keseluruhannya. (Marimba, 1989:67-68).

Jadi karakter artinya kepribadian yang secara keseluruhan aspeknya, sebagai perilaku yang ditampilkan, sesuai dengan ajaran Islam aktifitas kejiwaannya, falsafah hidup dan kepercayaannya menunjukkan rasa pengabdian dan penyerahan diri kepada Allah Swt.

Romantika Al-Qur'an Mengatakan:

Artinya: Dan Sesungguhnya kamu benar-benar berbudi pekerti yang agung. (QS. Al-Qalam:4).

Dari definisi ayat di atas dapat disimpulkan bahwa dalam menjabarkan karakter universal diperlukan bantuan pemikiran akal manusia dan kesempatan sosial yang terkandung dalam ajaran etika dan moral. Menghormati kedua orangtua misalnya adalah karakter yang bersifat mutlak dan universal. Sedangkan bagaimana bentuk dan cara menghormati orang tua itu dapat dimanifestasikan oleh hasil pemikiran manusia. Jadi, karakter Islam bersifat mengarahkan, membimbing, mendorong, membangun peradaban manusia dan mengobati bagi penyakit sosial dari jiwa dan mental, serta tujuan berkarakter yang baik untuk mendapatkan kebahagiaan di dunia dan akhirat.

Dalam proses penguatan karakter terhadap siswa, guru bidang studi aqidah akhlak berupaya mewujudkan tiga aspek karakter tersebut secara harmonis yaitu aspek kejasmanian, aspek kejiwaan, dan aspek keharmonisan, dengan mewujudkan ketiga aspek tersebut dapat menciptakan keseimbangan yang terpadu secara integritas karakter.

Yang dimaksud dengan integritas karakter ialah proses yang terpadu dari pembangunan karakter setiap manusia yaitu sesuatu pertumbuhan yang menumbuhkan kesatuan unsur-unsur jasmani dan rohaniah menjadi bangunan yang harmonis sebagai akibat terjalinnya mekanisme sistem pengaturan yang tertib, teratur dan rapi. (Suparlan, 1984:116)

Dalam menumbuhkan integrasi karakter manusia ini bidang studi aqidah akhlak berproses dalam mendinamisasi susunan karakter manusia. Adapun susunan karakter 
manusia yang harus mendapat pengaruh perubahan pendidikan, adalah: 1 . Nilai Religius; 2. Nilai Integritas; 3. Nilai Nasionalis; 4. Nilai Mandiri; 5. Nilai Gotong Royong; 6. Nilai sabar belajar mengaji.

Keenam susunan karakter manusia ini dalam bacaan Al-Qur'an berperan secara kompak dan harmonis, yang dalam pandangan lain harus terwujud dalam bentuk "amal shaleh", amal shaleh yang dimaksudkan disini adalah buah iman, akhlak dan ilmu. (Suparlan, 1984:117)

Dalam al-Qur'an Allah banyak menyuruh manusia untuk beramal shaleh disegala bidang dan kebanyakan ayat bahwa amal dikaitkan dengan iman, seperti firman Allah;

Artinya: "Sesungguhnya orang-orang yang beriman dan mengerjakan amal-amal saleh, mereka diberi petunjuk oleh Tuhan mereka karena keimanannya. (QS. Yunus: 9)".

Maksud ayat di atas adalah diberi petunjuk oleh Allah untuk mengerjakan amalamal yang menyampaikan surga.Amal shaleh yaitu apa saja yang dilakukan manusia untuk mendapatkan keridhaan Allah, untuk dirinya sendiri, keluarga, sesama manusia dan makhluk-makhluk lain.Maka seseorang yang beriman, berakhlak mulia senantiasa berbuat baik penuh semangat keimanannya, dan senantiasa mengikuti petunjuk yang benar dan inilah karakter yang dikehendaki.

Dari upaya guru ngaji dalam memperkuat karakter terhadap santri-santriwati di TPQ Al-Khairat Kota Bima sebagai karakter yang sejati.karakter itu menuntut adanya wujud manusia yang beriman, cinta kebaikan, mengetahui kebenaran dan sekaligus mengamalkannya.

\section{Karakter}

Secara etimologis, kata karakter (Inggris: character) berasal dari bahasa Yunani (Greek), yaitu charassein yang berarti "to engrave” (Bohlin, Karen E., \& Ryan, Kevin, 1999: 5). Kata "to engrave” bisa diterjemahkan mengukir, melukis, memahatkan, atau menggoreskan (Echols dan Shadily, 1987: 214).

Dalam Kamus Bahasa Indonesia kata "karakter" diartikan dengan tabiat, sifatsifat kejiwaan, akhlak atau budi pekerti yang membedakan seseorang dengan yang lain, dan watak.Karakter juga bisa berarti huruf, angka, ruang, simbul khusus yang dapat dimunculkan pada layar dengan papan ketik (Pusat Bahasa Depdiknas, 2008: 682). Orang berkarakter berarti orang yang berkepribadian, berperilaku, bersifat, bertabiat, atau berwatak.Dengan makna seperti ini berarti karakter identik dengan kepribadian atau akhlak. Kepribadian merupakan ciri atau karakteristik atau sifat khas dari diri seseorang yang bersumber dari bentukan-bentukan yang 
diterima dari lingkungan, misalnya keluarga pada masa kecil, dan juga bawaan sejak lahir (Koesoema, 2007: 80).

Secara terminologis, makna karakter dikemukakan oleh Thomas Lickona.Menurutnya karakter adalah "A reliable inner disposition to respond to situations in a morally good way. ”Selanjutnya Lickona menambahkan, “Character so conceived hasthree interrelated parts: moral knowing, moral feeling, and moral behavior" (Lickona, 1991:51). Menurut Lickona, karakter mulia (good character) meliputi pengetahuan tentang kebaikan, lalu menimbulkan komitmen (niat) terhadap kebaikan, dan akhirnya benar-benar melakukan kebaikan. Dengan kata lain, karakter mengacu kepada serangkaian pengetahuan (cognitives), sikap (attitides), dan motivasi (motivations), serta perilaku (behaviors) dan keterampilan (skills).

Dari pengertian di atas dapat dipahami bahwa karakter identik dengan akhlak, sehingga karakter merupakan nilai-nilai perilaku manusia yang universal yang meliputi seluruh aktivitas manusia, baik dalam rangka berhubungan dengan Tuhannya, dengan dirinya, dengan sesama manusia, maupun dengan lingkungannya, yang terwujud dalam pikiran, sikap, perasaan, perkataan, dan perbuatan berdasarkan norma-norma agama,hukum, tata karma, budaya, dan adat istiadat. Dari konsep karakter ini muncul konsep pendidikan karakter (character education).

\section{Bacaan Al-qur'an}

“Al-qur'an adalah" menurut pendapat yang paling kuat bererti "bacaan", asal kata Qaraa, kata Al-qur'an itu berbentuk masdar dengan arti isi maf'ul yaitu maqru (dibaca)". (Depag RI, 1989:5). Menurut istilah Al-qur'an adalah "Kalam Allah SWT", yang merupakan mu'zizat dan yang ditulis dimushab dan diriwayatkan secara mutawatir serta membacanya adalah ibadah.Didalamnya terkandung ajaran pokok yang dapat dikembangkan untuk keperluan seluruh aspek kehidupan melalui Ijtihad. Ajaran yang terkandung dalam Al-qur'an terdiri prinsip dasar yaitu yang berhubungan dengan masalah keimanan yang disebut dengan Ibadah dan yang berhubungan dengan amal yang disebut "syari'at". Al-qur'an sebagai sumber aspirasi dan wawasan serta pandangan universal, memberikan dorongan motivasi manusia untuk mengembangkan ilmu pengetahuan melalui rasio (akal pikiran) sejauh mungkin sampai pada zat Allah yang tidak mungkin oleh rasio itu.Setiap muslim mempunyai komitmen mengenal Al-Qur'an, mempelajarinya, mengamalkanya, dan mendakwahkanya. Dalam rangka mewujudkan 
komitmen ini Indonesia yang mayoritas penduduknya beragama Islam telah menjadikan Pendidikan Agama Islam sebagai salah satu mata pelajaran disetiap jenjang pendidikan formal. (Sukiman, 2003)

Bagi menguasai bacaan al-Qur'an yang betul dan tepat proses pengajaran dan pembelajaran al-Qur'an perlu dilakukan secara talaqqi dan mushafahah Perkataan talaqqi menepati maksud berjumpa atau berhadapan dan maksud mushafahah ialah bercakap dengan seseorang secara berhadapan. (Mustafa, 1996)

Membaca Al Qur'an bagi umat Islam merupakan ibadah kepada Allah SWT. Oleh karena itu, keterampilan membaca Al Qur'an perlu diberikan kepada anak sejak dini mungkin, sehingga nantinya diharapkan setelah dewasa dapat membaca, memahami dan mengamalkan Al Qur'an dengan baik dan benar.

Membaca Al-qur'an dengan tartil dan melagukan serta memperindahnya. Berdasarkan firmanya:

Artinya: "Dan bacalah al-Qur'an itu dengan tartil (perlahan-perlahan).” (AlMuzzammil:4).

Maksud ayat di atas, dituntut secara syar'i adalah memperindah suara, yang merupakan pendorong untuk mentadaburi al-Qur'an serta memahaminya, dan khusyu, tunduk, patuh, serta taat.

Keberhasilan suatu bangsa atau anak itu sendiri dalam memperoleh tujuanya tidak hanya ditentukan oleh melimpah ruahnya sumber daya alam, tetapi sangat ditentukan oleh kualitas sumber daya manusia. Bahkan, ada yang mengatakan, "Bangsa yang besar dapat dilihat dari kualitas/karakter bangsa (manusia) itu sendiri. (Majid \& Andayani, Dian 2011:2). Dalam sejarah Islam, sekitar 1400 Tahun yang lalu, Ibrahim (2002:141) menyatakan Nabi Muhammad SAW Sang Nabi terakhir dalam ajaran Islam, juga menegaskan bahwa misi utamanya dalam mengajar, mendidik, manusia adalah untuk menyempurnakan Akhlak, karna Akhlak Nabi itu sendiiri adalah Al-Qur'an, dan mengupayakan pembentukan karakter yang baik (Good Charakter).

Pemberian pelajaran Al Qur'an sebaiknya melalui tri pusat pendidikan yaitu : keluarga, sekolah dan masyarakat, dimana yang paling dominan dan waktunya banyak adalah di dalam keluarga. Oleh karena itu yang paling menentukan berhasil/tidaknya anak dapat membaca Al Qur'an adalah pendidikan informal di tengah keluarga.

Allah berfirman: 
Artinya: bacalah dengan (menyebut) nama Tuhanmu yang Menciptakan. Dia telah menciptakan manusia dari segumpal darah. Bacalah, dan Tuhan-mu lah yang Maha pemurah, yang mengajar (manusia) dengan perantaran kalam. Dia mengajar kepada manusia apa yang tidak diketahuinya. (QS. Al-A'laq:1-5).

Maksud ayat di atas, Allah mengajar manusia dengan perantaraan tulis baca. Membaca Al Qur'an bagi umat Islam merupakan ibadah kepada Allah SWT.Oleh karena itu keterampilan membaca Al Qur'an perlu diberikan kepada anak sejak dini mungkin, sehingga nantinya diharapkan setelah dewasa dapat membaca, memahami dan mengamalkan Al Qur'an dengan baik dan benar.

Pendidikan dalam masyarakat juga penting, karena anak lebih banyak bergaul dengan masyarakat yang dapat mempengaruhi sifat, watak dan perilakunya sehari-hari, karena pentingnya pengetahuan tentang Al Qur'an.

Didalam metode Iqra dapat dijadikan sesebuah kaedah alternatif bagi guru dalam pengajaran dan pembelajaran membaca al-Quran serta boleh menghantarkan murid mahir dalam membaca al-Quran. (Yusoff, Ahmad kamel Mohamed Mohd Alwi., \& Abdulaziz, Adel Mohd, 2010:51). Bacaan al-Qur'an di kalangan pelajar yang dikaji tidaklah berada pada tahap yang terlalu lemah.Walau bagaimanapun, kelemahan dan ketidakupayaan sebilangan pelajar untuk membaca al-Qur'an dengan baik dan lancar sebenarnya memang wujud. (Yakub, Saidi bin Mohd. Al-Bayan Mohd., \& Yusoff, Zulkifli bin Haji Mohd, 2008).

Pengajaran dan pembelajaran al-Quran hadits menggunanakan metode Iqra dapat meningkatkan kemampuan pelajar dalam membaca al-Quran, disamping itu, kaedah ini juga dapat meningkatkan kreatifitas pelajar dalam aktifitas pembelajaran dalam bilik darjah. Perkara di atas dapat dibuktikan apabila pelajar diajar menggunakan metode biasa berdasarkan statistik pada gelung pertama kemampuan pelajar hanya berada pada tahap sederhana (62\%). Manakala apabila mereka diajar dengan menggunakan metode Iqra analisis statistik menujukkan kemampuan siswa dapat meningkat mencapai tahap cemerlang (92\%). (Rendi, 2010:25).

Oleh karena itu, bagi guru agama Islam, selain mengajar pembelajaran al-Qur'an hadits dengan menggunakan metode iqro, guru agama Islam mengajarakan Implikasi kajian ialah guru Pendidikan Islam perlu senantiasa mempertingkatkan kemahiran pengajaran Tilawah al-Quran yang mereka miliki dengan cara yang paling efektif agar murid dapat menguasai Tilawah al-Qur'an dengan berkesan. (Tarmizi, Rohani Ahmad., 
\& Noh, Mohd Aderi Che, 2009:93). Dengan adanya pengajaran bacaan al-Qur'an atau Pendidikan al-Quran dengan jelasnya membuktikan bahawa ajaran-ajaran yang terkandung di dalamnya mampu memberi kejayaan dalam berbagai penyelidikan. Ahli sains mengambil al-Quran sebagai asas sains, ahli hukum mengeluarkan hukum daripada al-Quran, ahli falsafah membicarakan falsafah dalam al-Quran dan ahli pendidikan pula mengambil al-Quran sebagai dasar, kaedah, falsafah dan matlamat pendidikan. Oleh karena itu pendidikan al-Quran mestilah dijadikan teras dan sumber rujukan utama yang mendasari berbagai aspek kehidupan yang mampu membawa kajayaan terhadap kamajuan tamadun manusia. (Faisal, 2010:133).

\section{METODE PENELITIAN}

Peneliti ini merupakan penelitian lapangan dengan menggunakan pendekatan kualitatif yaitu suatu penelitian yang ditujukan untuk mendeskripsikan dan menganalisis fenomena, peristiwa, aktivitas sosial, sikap, kepercayaan, persepsi, pemikiran orang secara individual maupun kelompok.

Tempat penelitian dilaksanakan di TPQ Al-Khairat Ling. Rasabou, yang beralamat di kelurahan Jatibaru Kec. Asakota Kota Bima merupakan TPQ yang terunggul dalam Penguatan Nilai-nilai Karakter Santri-Santriwati Melalui Bacaan Al-Qur'an di Kota Bima. Selain itu juga TPQ Al-Khairat Ling. Rasabou juga merupakan ujung tombak perkembangan nilai-nilai karakter serta bacaan Al-Qur'an di TPQ Al-Khairat Ling. Rasabou.

Teknik analisis data merupakan upaya mencari dan menata secara sistematis catatan hasil observasi, wawancara dan lainnya untuk meningkatkan pemahaman peneliti tentang kasus yang diteliti dan menyajikannya sebagai temuan bagi orang lain. Dalam menganalisa data, peneliti menggunakan teknik deskriptif analitik, yaitu data yang diperoleh tidak dianalisa menggunakan rumusan statistika, namun data tersebut didetesiskan sehingga dapat memberikan kejelasan sesuai realita yang ada di lapangan. Hasil analisa berupa pemaparan gambaran mengenai situasi yang diteliti dalam bentuk uraian naratif. Uraian pemaparan harus sistematik dan menyeluruh sebagai satu kesatuan dalam konteks lingkungannya juga sistematik dalam penggunaannya sehingga urutan pemaparannya logis dan mudah diikuti maknanya. (Sujana, Nana dan Ibrahim, 1989:197198). Jadi analisis ini peneliti gunakan untuk menganalisa tentang bagaimana Penguatan 
Nilai-nilai Karakter Santri-Santriwati Melalui Bacaan Al-Qur'an di TPQ Al-Khairat Ling. Rasabou Kel. Jatibaru Kec. Asakota Kota Bima. Adapun langkah-langkah analisis yang peneliti lakukan selama di lapangan adalah: 1). Reduksi Data. Mereduksi data berarti merangkum, memilih hal-hal yang pokok, memfokuskan pada hal-hal yang penting, dicari tema dan polanya dan membuang yang tidak perlu. (Sugiyono, 2009:92). Dengan demikian data yang di reduksi akan memberikan gambaran yang cukup jelas. 2). Penyajian Data. Setelah data direduksi, maka langkah selanjutnya adalah mendisplaykan data, sehingga data dapat terorganisasikan dan dapat semakin mudah dipahami. 3). Penarikan Kesimpulan. Langkah ketiga adalah penarikan kesimpulan dan verifikasi. Kesimpulan awal yang ditemukan masih bersifat sementara dan akan berubah bila tidak ditemukan bukti-bukti yang kuat mendukung pada tahap pengumpulan data berikutnya. Tetapi apabila kesimpulan yang dikemukakan pada tahap awal didukung oleh bukti-bukti yang valid dan konsisten saat peneliti kembali kelapangan mengumpulkan data, maka kesimpulan yang dikemukakan merupakan kesimpulan yang kredibel.

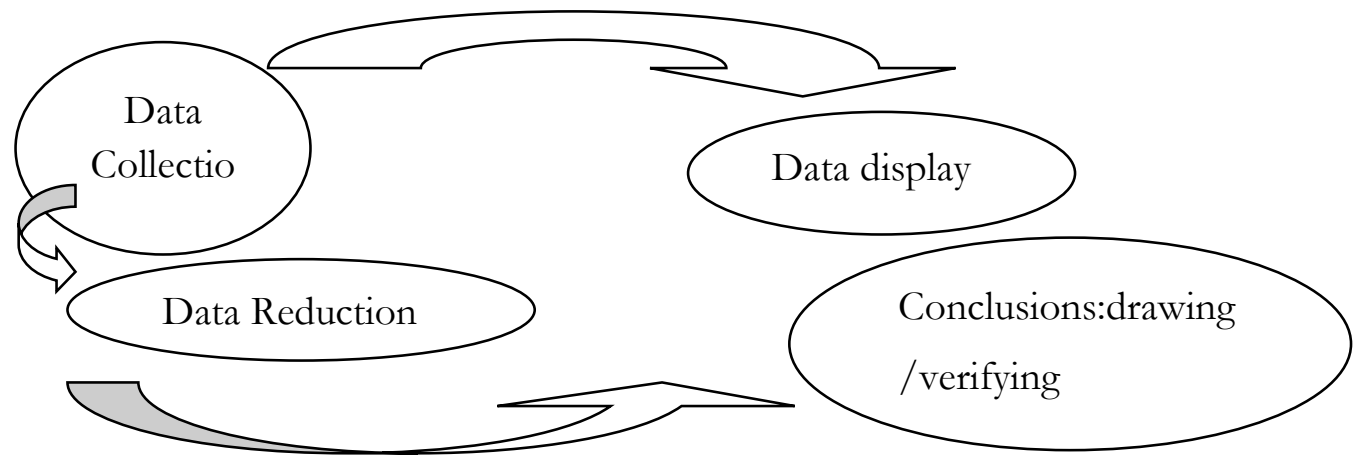

Gambar 1. Teknik Analisis Data

Berdasarkan paparan tersebut peneliti menggunakan teknik analisis kualitatif dalam penelitian untuk mengkaji "Penguatan Nilai-nilai Karakter Santri-Santriwati Melalui Bacaan Al-Qur'an diTPQ Al-Khairat Ling. Rasabou Kel. Jatibaru Kec. Asakota Kota Bima".

\section{HASIL PENELITIAN DAN PEMBAHASAN}

\section{Sejarah TPQ Al-Khairat}

TPQ Al-Khairat berdiri pada tanggal 12 Agustus 1999, TPQ ini merupakan TPQ tempat pengajian santri-santriwati dalam bacaan Al-Qur'an, dengan adanya pemikiran pembina TPQ Al-Khairatuntuk menyelenggarakan sebuah taman Al-Qur'an didasarkan 
semangat untuk menciptakan generasi Qur'ani yang memang harus digalakan agar membumi supaya santri-santriwati dapat memperkuat nilai-nilai karakter yang sudah ada dan dapat membentengi diri dengan akhlak dari kemajuan teknologi yang mengglobal.

Tenaga pengajar di TPQ Al-Khairat ini berjumlah 3 orang, yakni 2 orang pengajar laki-laki dan satu orang pengajar perempuan. Pengajar tersebut mengajarkan santrisantriwati dari Iqro sampai tahap Al-Qur'an hingga ia khatamkanya.

Jumlah santri-santriwati di TPQ Al-Khairat ini berjumlah 67 orang yakni santriberjumlah 38 orang sedangkan santriwatiberjumlah 29 orang diantaranya ada yang SD, SMP dan SMA, bahkan sudah ada yang tamat sekolah.

\section{Visi Misi TPQ Al-Khairat}

Misi dari TPQ Al-Khairat yakni:

a. Membangun akhlak religius

b. Pembinaan akhlak

Visi dari TPQ Al-Khairat adalah:

a. Pendidikan dan pembinaan diri cerdas Islami

b. Mengamalkan Al-Qur'an

\section{Tujuan TPQ Al-Khairat}

1. Agar anak terampil membaca, menulis, menghafal, memahami dan mengamalkan Al-Qur'an

2. Membentuk dan memperkuat karakter anak didik yang beriman, berilmu, beramal, dan bertakwa kepada Allah SWT

3. Mencerdaskan kehidupan bangsa melalui pendidikan Al-Qur'an.

Penguatan Nilai-nilai Karakter Santri-Santriwati Melalui Bacaan Al-Qur'an di TPQ Al-Khairat Ling. Rasabou Kel. Jatibaru Kec. Asakota Kota Bima

Penguatan nilai-nilai Karakter yang sudah ada pada diri santri-santriwati dan dikuatkan kembali nilai-niali tersebut melalui bacaan Al-Qur'an di TPQ Al-Khairat. Dengan demikian bacaan Al-Qur'an yang di ajarkan oleh guru ngaji di TPQ Al-Khairat dapat meningkatkan keimanan, penghayatan, pemahaman, serta dapat memperkuat karakter santri-santriwati.

Wawancara dengan pembina TPQ, Bapak Ridwan pada tanggal 01-11-2017 bahwa Penguatan nilai-nilai karakter santri-santriwati melalui bacaan al-qur'an di TPQ al-khairat ling. Rasabou kel. Jatibaru kec. Asakota Kota Bima terhadap santri-santriwati, sangat kuat terhadap kualitas dan kuantitas anak dalam 
mengembangkan bacaan Al-Qur'an, karena adanya penguatan karakter yang diajarkan kepada santri-santriwati. misalnya, selain mengajarkan nilai-nilai karakter santri-santriwati, maka santri-santriwati akan mulai mempertahankan nilai-nilai karakter yang sudah ada seperti Nilai Religius, Nilai Integritas, Nilai Nasionalis, Nilai Mandiri, Nilai Gotong Royong, Nilai sabar belajar mengaji. Bacaan Al-Qur'an pun yang dilaksanakan di TPQ Al-Khairat, juga salah satu faktor yang dapat memperkuat karakter santri-santriwati. Hal-hal yang seperti ini harus dibiasakan dalam kehidupan santri-santriwatisehari-hari.

Dari hal tersebut di atas, maka dapat dipahami bahwa bacaan al-qur'an sangat memperkuat nilai-nilai karakter santri-santriwati, terutama terhadap tingkah laku, ucapan yang baik, serta sapaan yang lemah lembut terhadap guru ngaji dan teman sebayanya serta rajinya santri-santriwati mengaji tiap harinya.

Nilai-nilai karakter yang diperkuat melalui bacaan Al-Qur'an yakni sebagai berikut:

\section{Nilai Religius}

1. Membumikan Al-Qur'an dengan cara magrib mengaji sesuai dengan program pemerintah kota bima

2. Membiasakan anak untuk berdoa sebelum dan sesudah baca Al-qur'an

3. Menugaskan anak untuk menghafal ayat-ayat pendek dan menyetorkan hafalanya setiap hari jum'at

4. Melakukan yasinan bersama pada setiap malam jum'at

5. Mengajak anak untuk sholat berjamaah di masjid/musholla

6. Memberikan contoh dan teladan yang baik dengan melakukan sholat dan mengaji

7. Mengontrol anak agar sholat tepat waktu (membiasakan anak menghargai waktu). (Wawancara dengan Abd Salam, guru ngaji tanggal 02-11-2017).

\section{Nilai Integritas}

1. Mengajarkan anak untuk berbicara apa adanya dan tidak suka bohong

2. Mengajarkan anak untuk mengakui kesalahan bila telah berbuat salah

3. Menunjukan pada anak tentang sikap jujur baik pada diri sendiri, keluarga dan orang lain yang didasarkan pada: bila berkata tidak bohong, bila berjanji tidak ingkar dan bila dipercaya harus bertanggung jawab

4. Menanamkan sikap jujur kepada anak harus diimbangi dengan perbuatan yang menjadi penilaian bagi diri sendiri dan menjadi contoh teladan bagi orang lain

5. Mengajarkan untuk selalu mengatakan sesuatu yang benar sekalipun pahit

6. Mengajarkan pada anak yang benar akan tetap dan yang benar akan mengantarkan orang untuk dipercaya

7. Membiasakan anak untuk memegang teguh pada komitmen dan tanggung jawab

\section{Nilai Nasionalis}

1. Menanamkan nilai kebangsaan kepada anak, bangga menjadi orang Indonesia lebih khusus orang bima 
2. Menanamkan nilai rela berkorban sebagai anak bangsa Indonesia, mengutamakan kepentingan bangsa dan negara, di atas kepentingan induvidu dan golongan

3. Mengisi kemerdekaan dengan berbuat yang bermanfaat untuk bangsa dan negara dan diri sendiri

4. Setiap hari besar seperti hari pahlawan, proklamasi kemerdekaan anak-anak dibimbing untuk mengenang jasa pahlawan dan mendoakan, semoga arwahnya diterima disisi Allah SWT

5. Mengajarkan pada anak untuk mengikuti upacara

6. Mengajarkan kepada anak untuk memelihara semangat, tekad, disiplin

7. Mengajarkan kepada anak untuk mengikuti gerakan pramuka. (Wawancara, Rahmania, S.Pd, Guru Ngaji TPQ Al-Khairat, pada tanggal, 03-11-2017).

\section{Nilai Mandiri}

1. Anak ditanamkan sikap patriotisme, ini harus terintegrasi dalam sikap dan kepribadian sebagai pribadi yang jujur, setia, suka menolong, dan berani menolak jika ada yang salah atau tidak benar

2. Berikan penghargaan pada anak jika dia berprestasi baik di sekolah maupun di lingkungan masyarakat khususnya di TPQ Al-Khairat Ling. Rasabou Kel. Jatibaru Kec. Asakota Kota Bima

3. Tidak ada kata terlambat dalam belajar

4. Membiasakan bekerja dengan jujur, amanah sesuai dengan perintah

5. Menanamkan sikap untuk mengutamakan kepentingan umum dari pada kepentingan pribadi dan golongan

6. Guru ngaji mengajarkan pada anak untuk berbuat baik

7. Guru ngaji mengajarkan pada anak untuk bekerja seperti berkebun dihalaman rumah, dan membersihkan rumah

\section{Nilai Gotong Royong}

1. Mendatangi rumah/tempat kegiatan sohibul hajat, tetangga yang sakit

2. Memberikan dukungan/bantuan sesuai kebutuhan dan kesepakatan

3. Melibatkan diri pada kegiatan kemasyarakatan untuk meringankan bebanya

4. Menghidupkan kembali budaya atau saling membantu tanpa upah

5. Membersihkan tempat pemakan umum

6. Membersihkan tempat-tempat ibadah, saluran air dilingkungan sekitar

7. Melibatkan diri secara sadar atau saling membantu dalam memakamkan warga yang meninggal dunia

\section{Nilai sabar belajar mengaji}

Santri-santriwati diajari oleh guru ngaji untuk selalu bersikap sabar terhadap teman-teman yang selalu berbuat jelek kepadanya sungguh lebih baik dari pada mencacinya. Mencaci lebih baik dari pada memutuskan tali silatuhrahmi.Dan memutuskan tali silatuhrahmi lebih baik dari pada bertengkar dengan teman sebayaku. (Wawancara, Nafisa, Santriwati TPQ Al-Khairat, pada tanggal, 04-11-2017) 
Perilaku yang menunjukkan upaya sungguh-sungguh dalam mengatasi berbagai permasalahan hidup, tugas dan menyelesaikan tugas dengan sebaik-baiknya.Sedangkan indikator di dalam kelas adalah santri-santriwati berusaha menciptakan suasana kompetisi yang sehat, menciptakan kondisi etos kerja, pantang menyerah dalam berbagai cobaan hidup, dan daya tahan belajar mengaji, menciptakan suasana belajar mengaji yang memacu daya tahan kerja, menciptakan ilmu bertahan dalam ejekan teman sebaya.

\section{Apa Makna dan Tujuan Baca Al-Qur'andi TPQ Al-Khairat?}

Dengan adanya makna serta tujuan mengajarkan baca Al-Qur'an dalam memperkuat karakter santri-santriwati agak sempurna dan hasilnya sudah memenuhi kriteria yang diharapkan.

Kendati demikian, bidang studi aqidah akhlak tidak hanya dapat memperkuat karakterNsantri-santriwati dalam hal hubungan langsung dengan Allah SWT akan tetapi juga dapat meningkatkan akhlak siswa dalam kehidupan sehari-hari.

Dengan belajar baca Al-Qur'ans antri-santriwati di TPQ Al-Khairat akan memiliki akhlak yang terpuji, baik kepada gurunya maupun antara sesama temantemannya, misalnya menghormati gurunya, baik ketika dalam ruangan mupun diluar ruangan, taat dan patut terhadap gurunya, serta tidak pernah lagi berkelahi sesama temannya. Mungkin ini semua berkat belajar bacaAl-Qur'an sehingga mengetahui mana yang baik dan mana yang buruk. (Wawancara, Furqan, Santri TPQ Al-Khairat, pada tanggal, 04-11-2017)

Dari pernyataan tersebut di atas, maka dapat dipahami bahwa baca Al-Qur'an sangat besar makna dan tujuannya terhadap penguatan nilai-nilai karakter santrisantriwati, sehingga dapat diaktualisasikan dalam kehidupan sehari-hari.

Adapun makna pelaksanaan baca Al-qur'an di TPQ Al-Khairat terdapat dua makna yakni: (Wawancara, Abd.Salam, M.Pd.I, Guru Ngaji TPQ Al-Khairat, pada tanggal, 05-11-2017)

1. Sebagai obat hati dan sarana perlindungan dari bahaya siksa di hari akhir

2. Sebagai bacaan mulia..

Tujuan pelaksanaan baca Al-qur'andi TPQ Al-Khairat adalah:

1. Menanamkan nilai-nilai Islam (Qur'ani) dan pendalaman pengetahuan keIslaman

2. Mengajarkan Santri-santriwati Baca tulis Al-Qur'an. 


\section{PENUTUP}

Berdasarkan hasil penelitian dengan menggunakan metode deskriptif, dengan pendekatan kualitatif, maka, dapat disimpulkan bahwa "Penguatan Nilai-nilai Karakter Santri-Santriwati Melalui Bacaan Al-Qur'an di TPQ Al-Khairat Ling. Rasabou Kel. Jatibaru Kec. Asakota Kota Bima”, dilakukan oleh guru ngaji di TPQ Al-Khairat dalam memperkuat nilai-nilai karakter yang sudah ada yakni: nilai religius, nilai integritas, nilai nasionalis, nilai mandiri, nilai gotong royong, nilai sabar belajar mengaji adalah dengan metode keteladanan sikap dan perilaku, pembiasaan, dan nasihat-nasihat yang diberikan. Adapun makna dan tujuan baca Al-qur'an di TPQ Al-Khairat sebagai berikut:

Makna pelaksanaan baca Al-qur'an di TPQ Al-Khairat yakni:

1. Sebagai obat hati dan sarana perlindungan dari bahaya siksa di hari akhir

2. Sebagai bacaan mulia

Tujuan pelaksanaan baca Al-qur'andi TPQ Al-Khairat

1. Menanamkan nilai-nilai Islam (Qur'ani) dan pendalaman pengetahuan ke-Islaman

2. Mengajarkan Santri-santriwati Baca tulis Al-Qur'an.

\section{DAFTAR PUSTAKA}

Andayani, Dian \& Majid. (2011). Pendidikan Karakter Dalam Prespektif Islam. Bandung: PT. Remaja Rosdakarya.

Bohlin, Karen E., \& Ryan, Kevin. (1999). Buliding Character in Schools: Pratical Ways to Bring Moral Instruction to Life. San Francisco: Jossey Bass.

Daradjat, Zakiah. (1993). Dasar-dasar Agama Islam (Cet. VIII). Jakarta: Bulan Bintang. Departemen Pendidikan Nasional. (2008). Kamus Bahasa Indonesia (Cet. I). Jakarta: Pusat Bahasa.

Echolis, John., \& Shadily, Hassan M. (1987). Kamus Inggris Indonesia (10 ${ }^{\text {th }}$ ed). Jakarta: Gramedia.

Faisal, Zawawi Ismail Rahimi Mohd Saad Mohd. (2010). Journal for Islamic Educational Studies, (1) 1.

Ibrahim, Hasan. (2002). Sejarah kebudayaan Islam, (H. A. Bahuddin, Penerjemah). Jakarta: Kalam Mulia. 
Koesoema, A Doni. (2007). Pendidikan Karakter: Strategi Mendidik Anak di Zaman Global. Jakarta: Grasindo.

Lickona, Thomas. (1991). Educating For Character: How Our School Can Teach Respect and Responsibility. Now York, Toronto, London, Sydney, Aucland: Bantam books.

Marimba, Ahmad D. (1989). Pengantar Filsafat Pendidikan Islam, (Cet. VIII). Bandung : PT. Al-Ma'arif.

Mustafa, Sheikh Husin Sabah. (1996). Muhadarah fi Turuq Tadris Madah al-Tajwid, Jurnal Institiut Pengajian Tahfiz al-Qur'an, Bahagian Hal Ehwal Islam. Jabatan Perdana Menteri.

Rendi, Abdulrohman. (2010). International Journal for Islamic Educational Studies (1) 1.

Salahudin, Anas., \& Alkrienciehie, Irwanto. (2013). Pendidikan Karakter, Pendidikan Berbasis Agama dan Budaya Bangsa, Bandung: Pustaka Setia.

Sudjana, Nana., \& Ibrahim. (1989). Penelitian dan Penelitian Kualitatif. Bandung: Sinar Baru.

Sugiyono. (2010). Metode Penelitian Pendidikan Pendekatan Kuantitatif, Kualitatif dan $R \& D$. Bandung: Alfabeta.

Sukiman, Usan. (2003). Pemberdayaan Pendidikan Agama Islam (PAI) di SekolahSekolah Umum". Jumal llmu Pendidikan lslam Kajian tentang Konsep, ProbIem dan Prospek Pendidikan lslam, Vol. 4, No. 2, Juli.

Suparlan, Suryapratondo. (1984). Ilmu Jiwa Kepribadian. Jakarta : PT. Paryu Berkah.

Tarmizi, Rohani Ahmad., \& Noh, Mohd Aderi Che. (2009). Jurnal Pendidikan Malaysia 34(1).

Yakub, Saidi bin Mohd. Al-Bayan Mohd., \& Yusoff, Zulkifli bin Haji Mohd. (2008) Journal of Al-Quran \& al-Hadith 1 (6).

Yusoff, Ahmad kamel Mohamed Mohd Alwi., \& Abdulaziz, Adel Mohd. (2010). Journal Studi Al-Quran and Islamic Educations 3 (2). 